\title{
Morphogenic and structural characteristics of tropical forage grasses managed under different regrowth periods in the Brazilian semi-arid region
}

\section{Características morfogênicas e estruturais de gramíneas forrageiras tropicais manejadas com diferentes períodos de rebrotação no semiárido brasileiro}

\author{
Genildo Fonseca Pereira ${ }^{1 *}$; João Virgínio Emerenciano Neto²; Gelson dos Santos \\ Difante $^{3}$; Liz Carolina da Silva Lagos Cortes Assis ${ }^{4}$; Patrícia de Oliveira Lima ${ }^{4}$
}

\begin{abstract}
The objective of this study was to evaluate the morphogenetic and structural characteristics of tropical grasses managed under different regrowth periods. The experiment was conducted at the Federal Institute of Science and Technology Education of Rio Grande do Norte, located in the municipality of Apodi-RN, Brazil. The study design was in randomized blocks and the treatments were allocated in a $3 \times 4$ factorial arrangement, with three cultivars (Andropogon, Buffel and Massai) in four regrowth periods $(21,35,49$ and 63 days). The interaction between cultivar and age was significant for all studied variables, with the exception of leaf blade width and accumulation rate. The highest leaf appearance rates were observed in Buffel grass, regardless of the regrowth age. This characteristic was not influenced by age only in Andropogon grass. Higher stem elongation rates were observed in Buffel grass, while the lowest were observed in Massai grass until 35 days of regrowth, attributed to the presence of inflorescences. Canopy heights in Massai and Andropogon grass were greater than Buffel grass until 35 days of regrowth, Andropogon grass had higher height from 35 days of regrowth than the others. Andropogon grass showed higher rates of accumulation than Massai grass only at 21 days of regrowth, and no effects of regrowth age were observed for this variable. Buffel grass should be defoliated at 21 days, while Andropogon and Massai grass can be managed without losses between 21 and 63 days of regrowth.
\end{abstract}

Key words: Andropogon gayanus. Cenchrus ciliares. Panicum maximum.

\section{Resumo}

Objetivou-se avaliar as características morfogênicas e estruturais de gramíneas tropicais manejadas sob diferentes períodos de rebrotação. O experimento foi conduzido no Instituto Federal de Educação Ciência e Tecnologia do Rio Grande do Norte, localizado no município de Apodi-RN. O delineamento foi em blocos ao acaso e os tratamentos foram alocados em arranjo fatorial $3 \times 4$, sendo três cultivares (Andropogon, Buffel e Massai) em quatro períodos de rebrotação (21, 35, 49 e 63 dias). A interação entre cultivar e idade foi significativa para todas as variáveis estudadas, com exceção da largura da lâmina

1 Prof., Instituto Federal de Educação, Ciência e Tecnologia do Rio Grande do Norte, IFRN, Apodi, RN, Brasil. E-mail: genildo. pereira@ifrn.edu.br

2 Prof., Universidade Federal do Vale do São Francisco, UNIVASF, Petrolina, PE, Brasil. E-mail: joao_neto@zootecnista.com.br

3 Prof., Universidade Federal do Mato Grosso do Sul, UFMS, Campo Grande, MS, Brasil. E-mail: gdifante@hotmail.com

4 Profs., Universidade Federal Rural do Semi-Árido, UFERSA, Mossoró, RN, Brasil. E-mail: liz@ufersa.edu.br; pattlima@ufersa. edu.br

* Author for correspondence 
foliar e da taxa de acúmulo. As maiores taxas de aparecimento de folhas foram observadas no capimbuffel, independentemente da idade de rebrotação. Apenas no capim-andropogon, essa característica não foi influenciada pela idade. As maiores taxas de alongamento de colmo foram observadas no capimbuffel e as menores no capim-massai até os 35 dias de rebrotação, atribuído a presença de inflorescências. As alturas do dossel dos capim-massai e capim-andropogon foram maiores que a do capim-buffel até os 35 dias rebrotação, a partir dos 35 dias de rebrotação o capim-andropogon apresentou maior altura que os demais. O capim-andropogon obteve maior taxa de acúmulo que o capim-massai apenas aos 21 dias de rebrotação. O capim-buffel deve ser desfolhado aos 21 dias, enquanto que os capins andropogon e massai podem ser manejados sem prejuízos entre 21 e 63 dias de rebrotação.

Palavras-chave: Andropogon gayanus. Cenchrus ciliares. Panicum maximum.

\section{Introduction}

Livestock is one of the main economic sources of the northeast Brazilian semiarid region, however the production system is extensive, using the Caatinga Biome vegetation as a base for feeding livestock (EMERENCIANO NETO et al., 2011). Due to irregular rainfall periods and places along with inefficient management, this biome has suffered from overgrazing and deforestation; practices that may jeopardize the activity's sustainability in the region.

In order to maintain livestock farming as economically and environmentally sustainable in northeastern Brazil, investment in research that seeks to understand forages with potential use in the region is necessary, since the competitiveness of Brazilian livestock farming is based on the production of fodder obtained from cultivated pastures (BARCELLOS et al., 2008). Thus, identifying forage cultivars adapted to the semiarid region can contribute to reducing deforestation of the Caatinga Biome.

In this sense, understanding morphogenetic and structural characteristics has the objective to identify and plan management strategies with forage to ensure longevity, productivity and sustainability to the ecosystem (PEREIRA et al., 2011). Understanding forage production dynamics in the pasture can be obtained by studying morphogenesis, which is described by four main characteristics in tropical pastures: leaf appearance rate, leaf elongation rate, leaf life span, and stem elongation rate (LEMAIRE et al., 2009).
In forage management, a balance between maintaining sufficient leaf area for photosynthesis and harvesting large amounts of leaf before senescence needs to be found in order to favor rational and efficient use of the pastures (DIFANTE et al., 2011).

In view of the above, this study was carried out with the objective of evaluating the morphogenetic and structural characteristics of the tropical grasses: Andropogon grass (Andropogon gayanus Kunth, cv. Planaltina), Buffel grass (Cenchru ciliaris cv. Grass) and Massai grass (Panicum maximum $\mathrm{x}$ Panicum infestum cv. Massai) at different regrowth ages.

\section{Materials and Methods}

This experiment was conducted at the Federal Institute of Science and Technology Education of Rio Grande do Norte - IFRN, Apodi campus, located in the municipality of Apodi - RN, west potiguar meso-region, with geographical coordinates of: Latitude $5^{\circ} 39^{\prime} 51^{\prime \prime}$ South elongitude: $37^{\circ} 47^{\prime} 56^{\prime \prime}$ West. The experimental period was from June to December 2014.

The soil of the area (Table 1) is classified as Eutrophic Cambisols (EMBRAPA, 2013). Fertilization was carried out with $60 \mathrm{~kg} \mathrm{ha}^{-1}$ year of phosphorus in the form of single superphosphate and $150 \mathrm{~kg} \mathrm{ha}^{-1}$ year of nitrogen in the form of urea. Nitrogen fertilization was carried out in two applications: the first with $75 \mathrm{~kg} \mathrm{ha}^{-1} \mathrm{~N}$ shortly after thinning the forage plants in April 2014, and 
the second with $75 \mathrm{~kg} \mathrm{ha}^{-1} \mathrm{~N}$ in September 2014. The climate of the region is BSh'W according to the Koppen classification, presenting a rainy season in January to July. The historical minimum and maximum temperatures are 21 and $37^{\circ} \mathrm{C}$, the average annual accumulation of rains is 600 to 700 $\mathrm{mm}$, and the relative humidity of the air oscillates between 50 and $70 \%$. Mean minimum and maximum temperatures in the experimental period were 21.29 and $36.81^{\circ} \mathrm{C}$, respectively, while the accumulated rainfall was $56.80 \mathrm{~mm}$, without precipitation in the months of August, October and December.

Table 1. Chemical characteristics of soil samples from the experimental area.

\begin{tabular}{|c|c|c|c|c|c|c|c|c|c|c|}
\hline \multirow{2}{*}{ MO (\%) } & $\mathrm{P}$ & $\mathrm{K}$ & $\mathrm{Na}$ & \multirow{2}{*}{$\mathrm{pH}$} & $\mathrm{Ca}$ & $\mathrm{Mg}$ & $\mathrm{Al}$ & $\mathrm{H}^{+} \mathrm{Al}$ & $\mathrm{CTC}^{\mathrm{e}}$ & \multirow{2}{*}{ V (\%) } \\
\hline & \multicolumn{3}{|c|}{$\mathrm{mg} \mathrm{dm}{ }^{-3}$} & & \multicolumn{5}{|c|}{$\mathrm{cmol}_{\mathrm{c}} \mathrm{dm}^{-3}$} & \\
\hline 0.6 & 2.0 & 207.0 & 16.0 & 6.1 & 3.0 & 1.1 & 0.0 & 1.6 & 4.6 & 74.3 \\
\hline
\end{tabular}

Sprinkler irrigation was used during the experiment with a precipitation of approximately $8.30 \mathrm{~mm} \mathrm{day}^{-1}$ in the months of January to June, and increased to $12.45 \mathrm{~mm}^{-1 a y^{-1}}$ in the months of July to December, with irrigation for 3 hours every two days. The experimental period was from June to December 2014.

The evaluated forage cultivars were Andropogon grass (Andropogon gayanus Kunth), cv. Planaltina, Buffel grass (Cenchrus ciliares, cv. Grass) and Massai grass (Panicum maximum x Panicum infestum, cv. Massai), in regrowth periods of 21, 35, 49 and 63 days using a $3 \times 4$ factorial arrangement.

Seeding was carried out in January 2014 in plots of $5 \mathrm{~m} \times 5 \mathrm{~m}\left(25 \mathrm{~m}^{2}\right)$, with $0.30 \mathrm{~m}$ spacing between rows and $1.0 \mathrm{~m}$ between plots, and the forage was kept in free growth until June when a uniform cut was performed at $0.20 \mathrm{~m}$ from the soil, being the height used for all cuts. The borders were $1.0 \mathrm{~m}$ with plot areas of $16 \mathrm{~m}^{2}$. Ten tillers per plot were randomly selected after each cut, corresponding to fifty tillers evaluated for each regrowth age, totaling 200 tillers (04 periods x 50 tillers). The evaluations were carried out every seven days by collecting information regarding the number of live leaves per tiller, length of leaf blade, leaf blade width and canopy height.

Leaf appearance rate was calculated by dividing the total number of leaves that appeared in the tiller by the regrowth period (LAR, leaf tiller ${ }^{-1}$. day). Phyllochron was estimated as the inverse of leaf appearance rate (Phylloc, days leaf ${ }^{-1}$.tiller) (SKINNER; NELSON, 1995). Leaf elongation rate was calculated by dividing the accumulated leaf length in the tiller by the period of evaluation days $(\mathrm{cm}$ tiller $^{-1}$.day). Stem elongation rate was calculated by dividing the accumulated pseudostem length (stem + sheath) in the tiller by the period of evaluation days (SER, cm tiller ${ }^{-1}$.day). Final leaf length was calculated by the product of leaf expansion rate and the elongation period duration for a given leaf $(\mathrm{cm}$ tiller $^{-1}$ ). The number of live leaves per tiller was always obtained by the maximum number of leaves during the evaluation period (NLL, leaf tiller-1). Leaf blade width was measured in the central region of the last expanded leaf $(\mathrm{cm})$.

Average pasture height was determined using a one-meter ruler graduated in centimeters in 15 representative points per plot, measuring the average height of the curvature of the leaf around the ruler.

Forage accumulation rate was determined by the ratio between the forage production of each cut and the interval between them. After eliminating borders, the forage mass of the area was cut and weighed to determine green mass. Two sub-samples were collected: one for determining total dry matter, and the other put into the forced ventilation oven at $55^{\circ} \mathrm{C}$ for 72 hours to determine dry weight. 
The applied design was randomized blocks, with treatments in a $3 \times 4$ factorial arrangement (three grasses $\mathrm{x}$ four regrowth periods). Data were submitted to analysis of variance and to the F test $(\alpha=0.05)$ when significant; the means and/or interactions were compared by the Tukey hypothesis test for the grasses, and by regression analysis for the regrowth periods. The following model was used: Yijk: $\mu+\mathrm{Ci}+\mathrm{Tj}+\left(\mathrm{C}^{*} \mathrm{~K}\right) \mathrm{ij}+\mathrm{Bk}$ + aijk . Where, Yijk $=$ observation of grass $\mathrm{i}$ at age j, block k; $\mu=$ mean overall effect; $\mathrm{Ci}=$ effect of grass $\mathrm{i}, \mathrm{i}=$ Andropogon, Buffel and Massai; $\mathrm{Tj}=$ effect of regrowth age $j, j=21,35,49$ and 63 days; $\left(\mathrm{C}^{*} \mathrm{~K}\right) \mathrm{ij}=$ effect of the interaction between grass $\mathrm{i}$ and age i; Bk = effect of block k; aijk: Random error associated with each ijk observation.

\section{Results and Discussion}

The interaction between cultivar and age was significant $(p<0.05)$ for all studied variables, except for leaf blade width and forage accumulation rate. No differences were observed in leaf appearance rate (LAR) between Andropogon and Massai grass (Table 2), however they differed from Buffel grass $(p<0.05)$ which had higher LAR, regardless of the regrowth age. Andropogon grass LAR was not influenced by regrowth periods, with an average of 0.061 leaves tiller ${ }^{-1}$.day. This behavior may indicate that Andropogon grass remains in a vegetative development, with regular leaf appearance up to 63 days of regrowth.

Table 2. Mean rates of leaf appearance, leaf elongation, stem elongation and phyllochron in Andropogon, Buffel and Massai grasses at different regrowth periods.

\begin{tabular}{|c|c|c|c|c|c|c|}
\hline \multirow{2}{*}{ Cultivars } & \multicolumn{4}{|c|}{----------- Age (Day) ----------- } & \multirow{2}{*}{ Equation } & \multirow{2}{*}{$\mathrm{R}^{2}(\%)$} \\
\hline & 21 & 35 & 49 & 63 & & \\
\hline \multicolumn{7}{|c|}{ Leaf appearance rate (leaf tiller-1 day) $(\mathrm{CV}=25.21 \%)$} \\
\hline Andropogon & $0.07^{\mathrm{b}}$ & $0.07^{\mathrm{b}}$ & $0.05^{\mathrm{b}}$ & $0.05^{\mathrm{b}}$ & $\hat{Y}=0.06$ & -- \\
\hline Buffel & $0.45^{\mathrm{a}}$ & $0.24^{\mathrm{a}}$ & $0.17^{\mathrm{a}}$ & $0.10^{\mathrm{a}}$ & $y=0.576-0.008 x$ & 90.90 \\
\hline Massai & $0.09^{\mathrm{b}}$ & $0.07^{\mathrm{b}}$ & $0.05^{\mathrm{b}}$ & $0.04^{\mathrm{b}}$ & $y=0.113-0.001 x$ & 98.44 \\
\hline \multicolumn{7}{|c|}{ Leaf elongation rate $\left(\mathrm{cm}\right.$ tiller ${ }^{-1}$ day $)(C V=20.44 \%)$} \\
\hline Andropogon & $2.13^{\mathrm{a}}$ & $2.04^{\mathrm{b}}$ & $2.37^{\mathrm{b}}$ & $2.56^{\mathrm{b}}$ & $\hat{Y}=2.27$ & -- \\
\hline Buffel & $2.02^{\mathrm{a}}$ & $3.05^{\mathrm{a}}$ & $4.82^{\mathrm{a}}$ & $5.57^{\mathrm{a}}$ & $y=0.140+0.088 x$ & 97.81 \\
\hline Massai & $2.45^{\mathrm{a}}$ & $1.74^{\mathrm{b}}$ & $2.68^{\mathrm{b}}$ & $3.44^{\mathrm{b}}$ & $\hat{Y}=2.58$ & -- \\
\hline \multicolumn{7}{|c|}{ Stem elongation rate $\left(\mathrm{cm}\right.$ tiller $^{-1}$ day $)(\mathrm{CV}=22.45 \%)$} \\
\hline Andropogon & $0.29^{\mathrm{b}}$ & $0.36^{\mathrm{b}}$ & $0.27^{\mathrm{a}}$ & $0.42^{\mathrm{a}}$ & $\hat{\mathrm{Y}}=0.33$ & -- \\
\hline Buffel & $0.74^{\mathrm{a}}$ & $0.40^{\mathrm{a}}$ & $0.26^{\mathrm{a}}$ & $0.24^{\mathrm{b}}$ & $y=0.9063-0.011 x$ & 84.09 \\
\hline Massai & $0.18^{\mathrm{c}}$ & $0.13^{\mathrm{c}}$ & $0.11^{\mathrm{c}}$ & $0.10^{\mathrm{c}}$ & $\hat{\mathrm{Y}}=0.13$ & -- \\
\hline \multicolumn{7}{|c|}{ Phyllochron $\left(\right.$ day leaf $\left.{ }^{-1}\right)(C V=17.65 \%)$} \\
\hline Andropogon & $15.74^{\mathrm{a}}$ & $14.27^{\mathrm{a}}$ & $18.90^{\mathrm{a}}$ & $19.55^{\mathrm{b}}$ & $y=12.300+0.114 x$ & 67.42 \\
\hline Buffel & $2.25^{\mathrm{c}}$ & $4.53^{\mathrm{b}}$ & $6.02^{\mathrm{b}}$ & $10.07^{\mathrm{c}}$ & $\mathrm{y}=1.771+0.178 \mathrm{x}$ & 95.83 \\
\hline Massai & $11.97^{\mathrm{b}}$ & $14.18^{\mathrm{a}}$ & $20.52^{\mathrm{a}}$ & $26.37^{\mathrm{a}}$ & $y=3.396+0.353 x$ & 96.55 \\
\hline
\end{tabular}

Means followed by distinct letters in the column do not differ from one another $(\mathrm{P}>0.05)$ by Tukey test.

Decreasing linear responses $(p<0.05)$ with a reduction in the LAR and an increase in regrowth age were observed in Buffel and Massai grasses. For each additional day in the Buffel grass regrowth period, the LAR value decreases by 0.008 leaf tiller ${ }^{-1}$ day, while this decrease in Massai grass was 0.001 leaf tiller ${ }^{-1}$.day. This decrease in the LAR value for Buffel grass can be explained by the rapid 
change of its physiological stage from vegetative to reproductive, considering that the assimilated nutrients are directed to form fruits, when the tiller is entering a reproductive state, its stem starts to lengthen, and the appearance of new leaf is interrupted. Leaf appearance rate is considered the central characteristic of morphogenesis, since it influences the structural components of the forage (DIFANTE et al., 2011).

No difference in leaf elongation rate was observed up to 21 days of regrowth $(p>0.05)$ between Andropogon, Buffel and Massai grasses; however, the highest leaf elongation rate was observed in Buffel grass at 35, 49 and 63 days of regrowth, indicating its greater capacity of leaf elongation with regrowth age advancement when compared to Andropogon and Massai grass. As Buffel grass tiller entered its reproductive stage, faster elongation may have occurred for flag leaves emission (SKINNER; NELSON, 1995), because leaf appearance rate decreased in the same period.

No effect of age on leaf elongation rate was observed in Andropogon grass and Massai $(p>0.05)$, while in Buffel grass adjusted the positive linear equation $(p<0.05)$ with an increase of 0.088 $\mathrm{cm}$ tiller $^{-1}$ for each additional day in the regrowth period. Sousa et al. (2010) also did not find any significant differences for Andropogon grass leaf elongation rate values in studies with different residual heights, with an average of $2.68 \mathrm{~cm}_{\text {tiller-1 }}$ day. Leaf elongation rate is of great relevance for the biomass flow of plants, since it is directly associated to the photosynthetic capacity of the plants with direct consequence on the production of forage (PACIULLO et al., 2017).

The highest stem elongation rates were observed in the Buffel grass $(p>0.05)$ and the lowest in the Massai grass until 35 days of regrowth. This result can be attributed to the presence of inflorescences in Buffel grass; however, at 63 days of regrowth, the highest stem elongation rates were observed in Andropogon grass and the lowest in Massai grass.
The greater stem elongation rates in Andropogon grass is the characteristic that makes this cultivar harder to handle, with serious consequences to leaf:stem ratio. Stem elongation rates differed among the regrowth periods in Buffel grass, where it was adjusted to the negative linear regression model. The phenotypic cycle of Buffel grass is very fast, and a reduction in stem elongation rates can be observed after 21 days of regrowth (LUNA et al., 2014), while no inflorescences were observed in the other cultivars during the whole experimental period, even with regrowth periods of 63 days. This characteristic is influenced by abiotic factors, so it responds differently according to the adopted management and the region's soil and climate conditions.

Phyllochron averages increased linearly as regrowth periods increased for all grasses. Andropogon grass had an increase of $24.17 \%$, Massai grass of $120.33 \%$, and Buffel grass of $347.93 \%$ in phyllochrome, from 21 to 63 days. This result corroborates the information that Buffel grass enters its reproductive stage up to 63 days of regrowth, and that Andropogon grass is a later grass regarding its physiological stage change.

The lowest phyllochron values observed in Buffel grass compared to the others may be associated to a shorter final length of the leaf blade and higher leaf elongation rates, which can decrease the time interval between the appearance of two consecutive leaves. The obtained values are consistent with those reported by Luna et al. (2014), who found phyllochron of 3.88 days leaf $^{-1}$ in Buffel and 10.4 days leaf ${ }^{-1}$ in Massai, with 30 days of regrowth. These are also consistent with Araújo et al. (2015), who observed phyllochron values of 10.5 days leaf $^{-1}$ in Andropogon.

The highest number of live leaves was observed in Buffel grass $(p<0.05)$ for all regrowth periods (Table 3). In Andropogon grass, the number of live leaves was adjusted to a linear and positive equation; the higher the age, the higher the number of live 
leaves, with an increase of $117 \%$ from the lowest to the highest age. In Buffel grass, the effect was also linear, but negative, with a reduction of $32.98 \%$ with an increase in age from 21 days to 63 days. The number of live leaves is a genetic characteristic of the species that is little affected by the environment in which the plant grows (PACIULLO et al., 2017). The reduction in the number of leaves must have occurred as a consequence of the change from the vegetative to the reproductive state, as nutrients are directed toward the formation of fruits when plants reach their maturity, rather than to new leaves. No effect of age for this variable was found in Massai grass, which had an average value of 2.3 leaves tiller-1. $^{-1}$.

Table 3. Average number of live leaves, final leaf length, leaf blade width, canopy height and forage accumulation rate in Andropogon, Buffel and Massai grasses at different regrowth periods.

\begin{tabular}{|c|c|c|c|c|c|c|}
\hline \multirow{2}{*}{ Cultivars } & \multicolumn{4}{|c|}{----------- Age (Day) ----------- } & \multirow{2}{*}{ Equation } & \multirow{2}{*}{$\mathrm{R}^{2}(\%)$} \\
\hline & 21 & 35 & 49 & 63 & & \\
\hline \multicolumn{7}{|c|}{ Number of live leaves (leaf tiller-1) $(\mathrm{CV}=19.55 \%)$} \\
\hline Andropogon & $1.49^{\mathrm{b}}$ & $2.47^{\mathrm{b}}$ & $2.59^{\mathrm{b}}$ & $3.24^{\mathrm{b}}$ & $y=0.84+0.038 x$ & 92.05 \\
\hline Buffel & $9.49^{\mathrm{a}}$ & $8.35^{\mathrm{a}}$ & $8.21^{\mathrm{a}}$ & $6.36^{\mathrm{a}}$ & $y=10.96-0.068 x$ & 90.35 \\
\hline Massai & $1.85^{\mathrm{b}}$ & $2.51^{\mathrm{b}}$ & $2.41^{\mathrm{b}}$ & $2.41^{\mathrm{b}}$ & $\hat{Y}=2.29$ & -- \\
\hline \multicolumn{7}{|c|}{ Final leaf length $(\mathrm{cm})(\mathrm{CV}=19.55 \%)$} \\
\hline Andropogon & $10.57^{\mathrm{a}}$ & $17.35^{\mathrm{a}}$ & $20.80^{\mathrm{a}}$ & $25.07^{\mathrm{a}}$ & $y=4.360+0.33 x$ & 97.84 \\
\hline Buffel & $10.41^{\mathrm{a}}$ & $11.72^{\mathrm{b}}$ & $10.24^{\mathrm{b}}$ & $11.35^{\mathrm{c}}$ & $\hat{\mathrm{Y}}=10.93$ & -- \\
\hline Massai & $10.38^{\mathrm{a}}$ & $20.50^{\mathrm{a}}$ & $18.72^{\mathrm{a}}$ & $19.58^{\mathrm{b}}$ & $y=-8.377+1.176 x+0.118 x^{2}$ & 83.81 \\
\hline \multicolumn{7}{|c|}{ Leaf blade width $(\mathrm{cm})(\mathrm{CV}=24.76 \%)$} \\
\hline Andropogon & $0.62^{\mathrm{a}}$ & $0.94^{\mathrm{a}}$ & $1.00^{\mathrm{a}}$ & $1.05^{\mathrm{a}}$ & $y=0.5018+0.0096 x$ & 80.33 \\
\hline Buffel & $0.47^{\mathrm{a}}$ & $0.50^{\mathrm{b}}$ & $0.52^{\mathrm{b}}$ & $0.49^{\mathrm{b}}$ & $\hat{\mathrm{Y}}=0.49$ & -- \\
\hline Massai & $0.62^{\mathrm{a}}$ & $0.66^{\mathrm{b}}$ & $0.58^{\mathrm{b}}$ & $0.58^{\mathrm{b}}$ & $\hat{\mathrm{Y}}=0.61$ & -- \\
\hline \multicolumn{7}{|c|}{ Canopy height $(\mathrm{cm})(\mathrm{CV}=12.26 \%)$} \\
\hline Andropogon & $33.92^{\mathrm{a}}$ & $40.36^{\mathrm{a}}$ & $54.44^{\mathrm{a}}$ & $63.30^{\mathrm{a}}$ & $y=17.339+0.730 x$ & 98.17 \\
\hline Buffel & $21.36^{\mathrm{b}}$ & $25.85^{\mathrm{b}}$ & $40.66^{\mathrm{b}}$ & $32.88^{\mathrm{c}}$ & $y=-8.397+1.667 x-0.0156 x^{2}$ & 74.65 \\
\hline Massai & $32.78^{\mathrm{a}}$ & $38.00^{\mathrm{a}}$ & $40.52^{\mathrm{b}}$ & $42.14^{\mathrm{b}}$ & $y=29.180+0.218 x$ & 93.23 \\
\hline \multicolumn{7}{|c|}{ Forage accumulation rate $\left(\mathrm{kg} \mathrm{ha}^{-1}\right.$ day $)(\mathrm{CV}=30.86 \%)$} \\
\hline Andropogon & $63.3^{\mathrm{a}}$ & $48.8^{\mathrm{a}}$ & $45.3^{\mathrm{a}}$ & $51.9^{\mathrm{a}}$ & $\hat{\mathrm{Y}}=52.3$ & - \\
\hline Buffel & $38.5^{\mathrm{ab}}$ & $43.3^{\mathrm{a}}$ & $38.2^{\mathrm{a}}$ & $30.3^{\mathrm{a}}$ & $\hat{Y}=37.6$ & - \\
\hline Massai & $30.9^{b}$ & $39.0^{\mathrm{a}}$ & $31.0^{\mathrm{a}}$ & $33.2^{\mathrm{a}}$ & $\hat{Y}=33.5$ & - \\
\hline
\end{tabular}

Means followed by the same lowercase letter in the column do not differ from one another $(p>0.05)$ by Tukey test.

Final leaf length had the same contrast as leaf elongation rate $(p>0.05)$, with no differences between grasses at 21 days of regrowth. From 35 days of regrowth, the grasses with the largest leaf elongation rate also had higher final leaf length. According to Lemaire et al. (2009), species with high leaf appearance rates tend to have shorter leaves, while species with low LAR tend to have longer leaves; a behavior observed in the present work.

Regrowth age had a linear effect on the final leaf length of Andropogon grass, with an increase of $137 \%$ from 21 to 63 days of regrowth, while the final leaf length of Massai grass adjusted to the quadratic 
model of regression (Table 2), with maximum leaf length of $20.95 \mathrm{~cm}$ at 50 days of regrowth. Final leaf length in Buffel grass was not affected by age, with a mean of $10.93 \mathrm{~cm}$. This result can be justified by the fact that Buffel grass was already in its reproductive stage at 21 days of age, demonstrating that final leaf length is affected by age and physiological status.

Leaf blade width did not differ between grasses up to 21 days. Leaf blade width was higher in Andropogon grass from this regrowth age, with no difference between the others. Only the leaf blade width of Andropogon grass was affected by the regrowth period adjusted to the positive linear equation, with an increase of $68.81 \%$ from 21 to 63 days. According to Moreira et al. (2015), leaf length and width are decisive factors in establishing the leaf area, allowing a greater interception of light and consequently higher photosynthesis rates.

Canopy heights in Andropogon and Massai grass were higher than Buffel grass up to 35 days regrowth. Andropogon grass had higher height than the others from this point on. This result is associated with higher stem elongation rates in Andropogon grass at this age (Table 2). Andropogon and Massai grass adjusted to positive and linear regression models according to the regrowth periods, with increments of 0.73 and $0.22 \mathrm{~cm}$ for each additional day of regrowth, respectively. Lopes et al. (2014) justify the increase in the canopy height as a result of the biological response of the forage, meaning that there is an increase of biomass and length of the plant with advance in age, especially of the pseudostem. Buffel grass fit the quadratic regression equation, with maximum canopy height of $35.87 \mathrm{~cm}$ at 53 days. The reduction after that time can be attributed to inflorescence drop, considering that this was already present at 21 days of regrowth.

Forage accumulation rate differed between cultivars only at 21 days of regrowth (Table 3 ); at that age, Andropogon grass forage accumulation rate was greater than for Massai grass. No effect of regrowth age was found on the forage accumulation rate of any of the cultivars $(\mathrm{P}>0.05)$. Emerenciano Neto et al. (2017) observed that the highest accumulation rates obtained in Massai grass pastures with greater regrowth periods are associated to the increment of dead material in the forage mass. The authors observed forage accumulation rate of $30.8 \mathrm{~kg} \mathrm{ha}^{-1}$ day DM in Massai grass with 73 days of regrowth, values close to those obtained in the present study.

Although no differences were observed in forage accumulation rates of pastures, morphogenic and structural differences should be considered in the cultivar choice. Early flowering in Buffel grass promotes unfavorable structural modifications to grazing, in addition to loss of nutritive value with flowering (TORO VELÁSQUEZ et al., 2010). On the other hand, the tolerance to the water deficit favors cultivation of this cultivar on the dry land of the property, although there is less tissue flow under these conditions. The stem elongation in Andropogon grass demands greater attention in the management, since it can easily pass the ideal defoliation point with long and excess stems which makes grazing difficult and reduces forage quality (MAGALHÃES et al., 2012). Massai grasses accept more flexible management when compared to Buffel and Andropogon grasses, since it can be used between 21 and 63 days of regrowth without major structural and productive variations. This phenotypic plasticity of the Massai grass suggests its indication as a forage option for grazing, hay production or pasture deferral.

Based on the morphogenic and structural responses of the Buffel, Andropogon and Massai grasses in the Brazilian semiarid region, it is possible to infer the use of the three cultivars in this biome as alternatives for diversification and pasture use management (21 days of regrowth), followed by the Andropogon grass and finally the Massai grass, justified by the lower stem length of this cultivar. 


\section{Conclusions}

Andropogon cv. Planaltina, Buffel cv. Grass and Massai grasses should be managed under different regrowth periods. Buffel grass should be defoliated at 21 days of regrowth in order to avoid reduction in the number of live leaves. Andropogon and Massai grasses can be managed between 21 and 63 days of regrowth, however the management of Andropogon grass becomes more difficult with advancement in the regrowth period due to stem elongation.

\section{References}

ARAÚJO, D. L. C.; OLIVEIRA, M. E.; LOPES, J. B.; ALVES, A. A.; RODRIGUES, M. M.; MOURA, R. L.; SANTOS, M. S. Características morfogênicas, estruturais e padrões demográficos de perfilhos em pastagem de capim-andropógon sob diferentes ofertas de forragem. Semina: Ciências Agrárias, Londrina, v. 36, n. 5, p. 3303-3314, 2015.

BARCELLOS, A. O.; RAMOS, A. K. B.; VILELA, L.; MARTHA JUNIOR, G. B. Sustentabilidade da produção animal baseada em pastagens consorciadas e no emprego de leguminosas exclusivas na forma de banco de proteína, nos trópicos brasileiros. Revista Brasileira de Zootecnia, Viçosa, MG, v. 37, p. 51-67. 2008. Suplemento Especial.

DIFANTE, G. S.; NASCIMENTO JÚNIOR, D.; SILVA, S. C.; EUCLIDES, V. P. B.; MONTAGNER, D. B.; SILVEIRA, M. C. T.; PENA, K. S. Características morfogênicas e estruturais do capim-marandu submetido a combinações de alturas e intervalos de corte. Revista Brasileira de Zootecnia, Viçosa, MG, v. 40, n. 5, p. 955963, 2011.

EMPRESA BRASILEIRA DE PESQUISA AGROPECUÁRIA - EMBRAPA. Centro Nacional de Pesquisa de Solo. Sistema brasileiro de classificação de solos. Rio de Janeiro: EMBRAPA Solos, 2013. 286 p.

EMERENCIANO NETO, J. V.; DIFANTE, G. S.; LANA, A. M. Q.; CAMPOS, N. R. F.; VERAS, E. L. L.; MORAES, J. D. Sward structure and herbage accumulation of massai guineagrass pastures managed according to pre-grazing heights, in the northeast of Brazil. Journal of Agricultural Science, Toronto, v. 9, n. 4, p. 155-163, 2017.

EMERENCIANO NETO, J. V.; PEREIRA, G. P.; MEDEIROS, H. R.; GRACINDO, A. P. A. C.; DIFANTE, G. S. Characterization and economic evaluation of smallholder production systems. Revista Brasileira de Agropecuaria Sustentavel, Viçosa, MG, v. 1, n. 1, p. 2128, 2011.

LEMAIRE, G.; SILVA, S. C.; AGNUSDEI, M.; WADE, M.; HODGSON, J. Interactions between leaf lifespan and defoliation frequency in temperate and tropical pastures: a review. Grass and Forage Science, Wiley, v. 64, n. 4, p. 341-353, 2009.

LOPES, M. N.; POMPEU, R. C. F. F.; SILVA, R. G.; REGADAS FILHO, J. G. L.; LACERDA, C. F.; BEZERRA, M. A. Fluxo de biomassa e estrutura do dossel em capim-braquiária manejado, sob lâminas de irrigação e idades de crescimento. Bioscience Journal, Uberlândia, v. 30, n. 5, p. 490-500, 2014.

LUNA, A. A.; DIFANTE, G. S.; MONTAGNER, D. B.; EMERENCIANO NETO, J. V.; ARAÚJO, I. M. M.; OLIVEIRA, L. E. C. Características morfogênicas e acúmulo de forragem de gramíneas forrageiras sob corte. Bioscience Journal, Uberlândia, v. 30, n. 6, p. 18031810, 2014.

MAGALHÃES, J. A.; CARNEIRO, M. S. S.; ANDRADE, A. C.; PEREIRA, E. S.; SOUTO, J. S.; PINTO, M. S. C.; RODRIGUES, B. H. N.; COSTA, N. L.; MOCHEL FILHO, W. J. E. Eficiência do nitrogênio, produtividade e composição do capim-andropogon sob irrigação e adubação. Archivos de Zootecnia, Córdoba, v. 61, n. 236, p. 577-588, 2012.

MOREIRA, J. A. S.; FAGUNDES, J. L.; MISTURA, C.; LEMOS, N. L. S.; MOREIRA, J. N.; BACKES, A. A.; MORAIS, J. A. S.; OLIVEIRA, C. S.; MOREIRA, A. L. Características morfogênicas, estruturais e produtivas de acessos de capim-buffel. Semina: Ciências Agrárias, Londrina, v. 36, n. 1, p. 391-400, 2015.

PACIULlO, D. S. C.; GOMIDE, C. A. M.; CASTRO, C. R. T.; MAURÍCIO, R. M.; FERNANDES, P. B.; MORENZ, M. J. F. Morphogenesis, biomass and nutritive value of Panicum maximum under different shade levels and fertilizer nitrogen rates. Grass and Forage Science, Wiley, v. 72, n. 3, p. 590-600, 2017.

PEREIRA, V. V.; FONSECA, D. M.; MARTUSCELLO, J. A.; BRAZ, T. G. S.; SANTOS, M. V.; CECON, P. R. Características morfogênicas e estruturais de capimmombaça em três densidades de cultivo adubado com nitrogênio. Revista Brasileira de Zootecnia, Viçosa, MG, v. 40, n. 12, p. 2681-2689, 2011.

SOUSA, B. M. L.; NASCIMENTO JÚNIOR, D.; SILVA, S. C.; MONTEIRO, H. C. F.; RODRIGUES, C. S.; FONSECA, D. M.; SILVEIRA, M. C. T.; SBRISSIA, A. F. Morphogenetic and structural characteristics of andropogon grass submitted to different cutting heights. 
Revista Brasileira de Zootecnia, Viçosa, MG, v. 39, n. 10, p. 2141-2147, 2010.

SKINNER, R. H.; NELSON, C. J. Effect of tiller trimming on phyllochron and tillering regulation during tall fescue development. Crop Science, Madison, v. 34, n. 5, p. 1267-1273, 1995.
TORO VELÁSQUEZ, P. A.; BERCHIELLI, T. T.; REIS, R. A.; RIVERA, A. R.; DIAN, P. H. M.; TEIXEIRA, I. A. M. A. Composição química, fracionamento de carboidratos e proteínas e digestibilidade in vitro de forrageiras tropicais em diferentes idades de corte. Revista Brasileira de Zootecnia, Viçosa, MG, v. 39, n. 6, p. 1206-1213, 2010. 
